\title{
User Antecedents, CRM Implementation, and Impact on Customer Outcomes in the Jordanian Service Industry
}

\author{
Muneer M. Abbad, Community College of Qatar, Qatar \\ Ibrahim Hussien Musa Magboul, Community College of Qatar, Qatar \\ Faten Jaber, Oxford Brookes University, UK \\ Wasfi Alrawabdeh, The Hashemite University, Jordan
}

\begin{abstract}
The implementation of customer relationship management (CRM) has become increasingly important to scholars and practitioners over the last two decades. This study examined the relationships between user antecedents, CRM implementation, and customer outcomes. Its aims were to identify CRM user antecedents, explore the impact of these antecedents on CRM implementation, and examine the connection between CRM implementation and customer outcomes: loyalty, retention, and satisfaction. A quantitative method was employed consisting of a structured questionnaire. A total of 290 completed questionnaires were returned and analyzed with structural equation modelling techniques. The results indicated there were significant positive relationships between four out of five antecedents and CRM implementation; however, an impact of user involvement was not supported by the data. CRM implementation was also found to positively affect all three customer's outcomes: loyalty, retention, and satisfaction. These findings are of practical and theoretical value to practitioners, customers, and policy makers.
\end{abstract}

\section{KEYWORDS}

CRM Implementation, Customer Loyalty, Customer Outcomes, Customer Relationship Management, Customer Retention, Customer Satisfaction, Service Industry Usage, User Antecedents

\section{INTRODUCTION}

In response to rapid changes in information technology (IT) and an increasingly competitive business environment, a large number of companies have implemented information system applications such as customer relationship management (CRM) over the past 10 years (Chen et al., 2020; Chiguvi \& Mahambo, 2020; Cruz-Jesus et al., 2019). CRM is a strategy and technique for handling customer interactions through IT usage to automate business processes (Anshari et al., 2019). It enables companies to collect, save, access, communicate, and analyze huge amounts of data about their customers (Suoniemi et al., 2021). Its implementation has 
been driven by the fact that numerous firms, particularly those working for service industries, wish to increase their knowledge of customer loyalty, retention, and satisfaction in order to remain competitive (Barsy, 2017; Santouridis \& Veraki, 2017). In line with Rahimi and Kozak (2017), Cruz-Jesus et al. (2019) asserted that the implementation of CRM strategies is a major marketing development, designed principally to generate and manage enduring customer relationships. This is expected to enable businesses to better understand their customers and retain them by providing an enhanced experience. Additionally, it attracts new customers, improves profitability, and reduces customer management expenses (Cherapanukorn, 2019; Shaon \& Rahman, 2015; Tawinunt et al., 2015). CRM therefore serves to enhance the company's connections with its customers to increase its market share and does so by assimilating people, processes, and technology to improve organizational performance (Cruz-Jesus et al., 2019; Sota et al., 2020; Rahimi, 2017). Enhancing the association with customers will increase customer loyalty, retention, and satisfaction (Anshari et al., 2019; Chen et al., 2020; Ngai, 2005). Although many CRM projects fail (Jaber \& Simkin, 2017; Nguyen et al., 2007), it can help managers understand the core value of customers for their organization or industry, along with their needs, wants, and views in order to improve planning and implementation (King \& Burgess, 2008; Salloum \& Ajaka, 2013).

Numerous organizations overspend when courting new customers and underspend when striving to retain existing customers (Kotler, 2003; Padma \& Wagenseil, 2018). For instance, at least 80 percent of marketing budgets is spent on attracting new customers, while the remainder is spent on retaining customers (Momanyi, 2010; Muketha et al., 2016). Thus, customer retention is a factor to which numerous firms attach little or no importance and are therefore unable to appreciate the advantages and value that customer retention provides. Research has indicated that not all retained customers are satisfied and, in some cases, only remain with the provider because there are no alternatives. Furthermore, it is evident that not every retained customer is satisfied - which reinforces the argument that it is only a lack of alternatives that persuades customers to stay with their current provider (Eriksson \& Vaghult, 2000; Parawansa, 2018).

There has been increasing interest in the field of customer management (Bhat et al., 2018). Hence, customers and customer relationships are becoming the central focus of organizations, many of which will find it considerably difficult to survive without a loyal customer base (KHOA, 2020). Consequently, numerous studies from a marketing perspective have demonstrated the benefits of customer retention within organizations (Ahmad \& Buttle, 2001; KHOA, 2020). Therefore, CRM is regarded as an orientation in which the customer is the crucial element that controls the system (Appiah-Kubi, 2010; Lemon \& Verhoef, 2016).

Research on the user antecedents of CRM implementation in different cultures and its effect on business performance is extremely limited, which restricts the generalizability of existing findings (Jaber \& Simkin, 2017). To address this paucity of research in developing countries (including Jordan), this study examined the impact of user antecedents on the implementation of CRM and its effect on customer outcomes (loyalty, retention, and satisfaction). Few studies have elucidated these relationships, and those that have been conducted were undertaken in developed countries.

In Jordan, the economy is emerging, and several international bodies are helping the country improve its digital services to step in the digital economy platforms. For instance, in 2019, the World Bank reported that the services sector, including the ICT sector, exhibited good potential for growth and job creation, with a growth rate of 2.3 percent in the previous year. This indicates that it is one of the fastest growing sectors toward digital transformation in Jordan. Moreover, the implementation and use of CRM in the service industry brings direct benefits in terms of both financial performance and daily business activity (Gil-Gomez et al., 2020). Therefore, this study aimed to investigate the user antecedents of CRM implementation and its impact on customer outcomes in the service industry in Jordan. 


\section{LITERATURE REVIEW}

\subsection{Customer Relationship Management}

CRM was originally referred to as "contact management" (Pai \& Tu, 2011). It is an American concept that emerged in the 1980s, along with its extended functions such as collecting customer data and gathering useful information, which subsequently developed into the call center. According to Swift (2001), CRM is an "enterprise approach to understanding and influencing customer behavior through meaningful communications in order to improve customer acquisition, customer retention, customer loyalty, and customer profitability" (p. 12). Similarly, Kotler and Armstrong (2008) claimed that CRM refers to "the overall process of building and maintaining profitable customer relationships by delivering superior customer value and satisfaction" (p. 16). Parvatiyer and Sheth (2001) described $\mathrm{CRM}$ as "a comprehensive strategy and process of acquiring, retaining, and partnering with selective customers to create superior value for the company and customer" (p. 5). These definitions indicate that customer loyalty, customer retention, and customer satisfaction are the main outcomes of CRM, thus becoming the primary focus of businesses and attracting the attention of scholars and practitioners.

A cross-functional supply chain, marketing, sales, and customer services are required for the effective implementation of CRM (Chen \& Popovich, 2003; Farhan et al., 2018; Lambert, 2009; Payne \& Frow, 2006). Jayachandram et al. (2005) described CRM as the interrelationship between three perspectives: management, marketing, and IT. Consequently, building a conceptual framework of CRM antecedents that facilitate effective CRM implementation involves the visualization of a combination of the three aforementioned perspectives from the viewpoint of both companies and customers. Although CRM development and implementation began in developed countries, it has quickly spread to developing countries (Jaber \& Simkin, 2017). However, the way businesses use and implement CRM in developing countries, particularly in the Arab world, is certainly different. This study focuses on the user antecedents of CRM that affect CRM implementation and enable it to achieve three key outcomes (customer loyalty, customer retention, and customer satisfaction) in the context of developing countries.

\subsection{Customer Relationship Management Implementation}

Most organizations seek to increase their profits through their relationships with customers, and invest in IT to manage this relationship more effectively (Kebede \& Tegegne, 2018). Kebede and Tegegne (2018) claimed that numerous benefits could be gained from implementing CRM such as reduced costs, increased revenue, and improved loyalty. Companies use CRM as a major source of competitive advantage, and to assist managers with making decisions related to customer benefits (Cruz-Jesus et al., 2019; Mohamed et al., 2014) and company's growth (Alrousan et al., 2020). However, based on the current competitive global environment and diversity of organizations, it is suggested that CRM implementation should be evaluated in different cultures and within different countries (Akroush et al., 2011; Olavarría-Jaraba et al., 2018).

Several studies focusing on CRM implementation have identified four key areas that must be considered for successful implementation: technology, process, people, and strategy (Akroush et al., 2011; Dubey \& Sangle, 2019; Sin et al., 2005; Sota et al., 2020; Rahimi, 2017). According to Cherapanukorn (2019), Hong-kit Yim et al. (2004), and Sin et al. (2005), there are also four behavioral dimensions that form part of a multidimensional construct for CRM: knowledge management, technology-based CRM, key customer focus, and CRM organization. Akroush et al. (2011) tested the generalizability of CRM implementation in the financial services industry in Jordan. Their results indicated that the scale of CRM implementation introduced by Sin et al. (2005) could be generalized to financial services organizations in Jordan. Other studies have concentrated on the critical phases of CRM implementation. For instance, Tan et al. (2002) formulated six stages for successful CRM implementation: identifying objectives, communicating, planning, designing, choosing a CRM system, 
and continually improving the process. Almotairi (2010) stated that cultural issues, which necessitate changes to the system to make it more effective in developing countries, complicate CRM application.

Since various countries and regions have different CRM practices and problems, it is difficult to compare and apply the findings from other studies to companies in developing countries (El-Gohary et al., 2013). Resultantly, further research is required to examine CRM implementation in these countries, which is becoming increasingly necessary (Khashab et al., 2020).

\subsection{Customer Relationship Management Implementation and Customer Outcomes}

CRM implementation can help companies improve customer loyalty, increase retention rates, and enhance customer satisfaction (Das et al., 2018; Mandina, 2014). The effect of implementing CRM on customer outcomes has been addressed by numerous studies. Thus, the outcomes from the productive implementation of CRM derive from businesses communicating with customers, identifying their behavior patterns, establishing their future needs and wants (Chen et al., 2020; Maklan \& Knox, 2009), creating value for customers, and resolving issues raised by dissatisfied customers (Payne \& Frow, 2006).

Therefore, companies are building relationships with customers because retention expenses are lower than customer acquisition, which will likely increase customer loyalty (Sheth \& Sharma, 2008; Tussyadiah, 2016). Accordingly, there is a consensus among marketing scholars that a better connection between firms and their customers will increase both customer loyalty and business profits (Suoniemi et al., 2021). Furthermore, Akroush et al. (2011) explained in their proposed model that CRM implementation measured by its four dimensions (knowledge management, technology-based CRM, key customer focus, and CRM organization) will positively impact business and marketing performances, of which customer satisfaction is the best indicator. Customer satisfaction refers to the extent to which the perceived service or product performance surpasses or matches customer expectations, and is considered a core-marketing concept (Kotler \& Armstrong, 2008; Roberts-Lombard, 2020). It is a cognitive evaluation by customers of their emotional state, and results from an evaluation of their overall relationship with a company (Arcond et al., 2017). CRM systems also offer numerous benefits for organizations, including improved customer satisfaction as well as increased organizational productivity and revenue (Rababah, 2013; Roberts-Lombard, 2020).

In addition to customer satisfaction, customer retention and loyalty are the main outcomes of CRM implementation (Chen et al., 2020; Dubey \& Sangle, 2019). Increasing customer retention significantly increases business profits (Saxena \& Taneja, 2018; Reichheld, 1996). The objective of customer retention is to reduce the number of customer defections, increase customer loyalty, and ensure customers return (Kebede \& Tegegne, 2018). Kotler and Keller (2016) defined customer loyalty as "a commitment that is held deeply to buy or support products or services that are preferred in the future, even though the influence of the situation and marketing efforts have the potential to cause customers to switch" (p. 138).

Trust refers to customers' confidence in the dependability and honesty of a firm, and is important in establishing a long-lasting relationship with customers (Fernandes \& Pinto, 2019). Bhat et al. (2018) found a strong relationship between loyalty and trust in the banking sector. The quality of the relationship with customers will therefore increase loyalty (Anshari et al., 2019; KHOA, 2020).

There is strong evidence in the CRM literature to connect successful CRM implementation with the receipt of CRM benefits in terms of customer loyalty (De Wulf et al., 2001; Kim et al., 2004; Nguyen, 2012), retention (Christy et al., 1996; KHOA, 2020), and satisfaction (Ambler \& Kokkinak, 1997; Doyle, 1995). Companies that implement CRM can thus improve customer loyalty, increase retention rates, and enhance customer satisfaction (Anshari et al., 2019; Qtaish et al., 2018). For this reason, companies that actively implement CRM have achieved such outcomes (Diffley et al., 2018; Dyché, 2002; Padmavathy et al. 2012). 


\subsection{User Antecedents of Customer Relationship Management Implementation}

To survive in a highly competitive business environment, companies focus on customers by implementing CRM. However, the implementation of CRM must be effective and yield the previously described outcomes. Studies that analyzing the antecedents of CRM implementation can be found at an organizational level (Pullig et al., 2002; Šebjan et al., 2014; Jaber and Simkin, 2017), and several researchers have also explored the adoption of CRM at an individual level from an information systems (IS) perspective (Jaber \& Simkin, 2017; Wu \& Wu, 2005). According to Jaber and Simkin (2017), employees' acceptance of CRM at an individual level can be explained by traditional IS adoption models such as the theory of reasoned action (Ajzen \& Fishbein, 1980), the technology acceptance model (Davis, 1989), the theory of planned behavior (Taylor \& Todd, 1995), the decomposed theory of planned behavior (Taylor \& Todd, 1995), the unified theory of acceptance and use of technology (Venkatesh et al., 2003), and innovation diffusion theory (Rogers, 1983). For example, Avlonitis and Panagopoulos (2005) employed the technology acceptance model (TAM) to study the antecedents and consequences of CRM in sales forces. The results indicated that the perceived usefulness of CRM has the strongest influence on CRM acceptance. They also concluded that other factors could affect CRM acceptance, such as accurate expectations, innovativeness, perceived ease of use, and influence of supervisors.

Day (2002) concluded that CRM users play a key role in CRM implementation through the organizational decisions they make. Jaber and Simkin (2017) reached the same conclusion and focused on the role of employee perceptions in mediating the effect of adoption factors and CRM implementation. They found that "employees attempt to judge the salient characteristics of the innovation from an attitude towards the innovation. Without such information (i.e., employee perceptions), organizations may hesitate to invest in CRM if there is uncertainty about the benefits and costs of implementing CRM" (p. 478). In organizational contexts, employees' perceptions of CRM outcomes will influence CRM implementation (Plakoyiannaki, 2005). This suggests that employees' needs should be aligned with CRM strategies to ensure successful CRM implementation (Day, 2002; Vella \& Caruana, 2012).

Numerous researchers have concentrated on the antecedents of CRM implementation from an IS point of view, along with the consequences of CRM adoption (Avlonities et al., 2005; Jaber \& Simkin, 2017). They contend that the implementation of CRM should be considered an antecedent of CRM use. Avlonities et al. (2005) classified the factors that can affect CRM acceptance into three categories: social, organizational, and individual. Other factors such as training and previous experience are requisite resources and skills that could affect CRM users' behavior (Avlonities et al., 2005; Dubey \& Sangle, 2019; Padilla-Meléndez \& Garrido-Moreno, 2014). Training in CRM will help users understand the operation of the system and its benefits for both the company and its customers (Avlonities et al., 2005). Employees' beliefs about the system and acceptance are linked to training (Davis et al., 1989; Igbaria, 1990). Furthermore, user involvement and participation will enhance user acceptance, increase satisfaction levels, and improve their perceptions of the efficiency of the system (Avlonities et al., 2005; Padma \& Wagenseil, 2018). The experience of CRM users plays an important role in CRM implementation because it influences their belief structure regarding an IS (Dubey \& Sangle, 2019; Igbaria, 1990). Trust is a crucial element in managing the relationship between companies and customers (Qtaish et al., 2018).

Several studies have concentrated on examining the antecedents that impact CRM implementation in a range of industries, including the financial services (Karakostas et al., 2005) and manufacturing industries (Wu \& Wu, 2005). However, empirical reviews of the antecedents and outcomes of CRM implementation are limited in developing countries. This study develops a research model and conducts cross-sectional empirical research to investigate the relationships between user antecedents, CRM implementation, and customer outcomes. Additionally, the existing research has mostly focused on how CRM implementation improves firm performance in developed countries, but only a limited number of studies have linked the three customer outcomes of loyalty, retention, and satisfaction. 
Figure 1. Proposed model

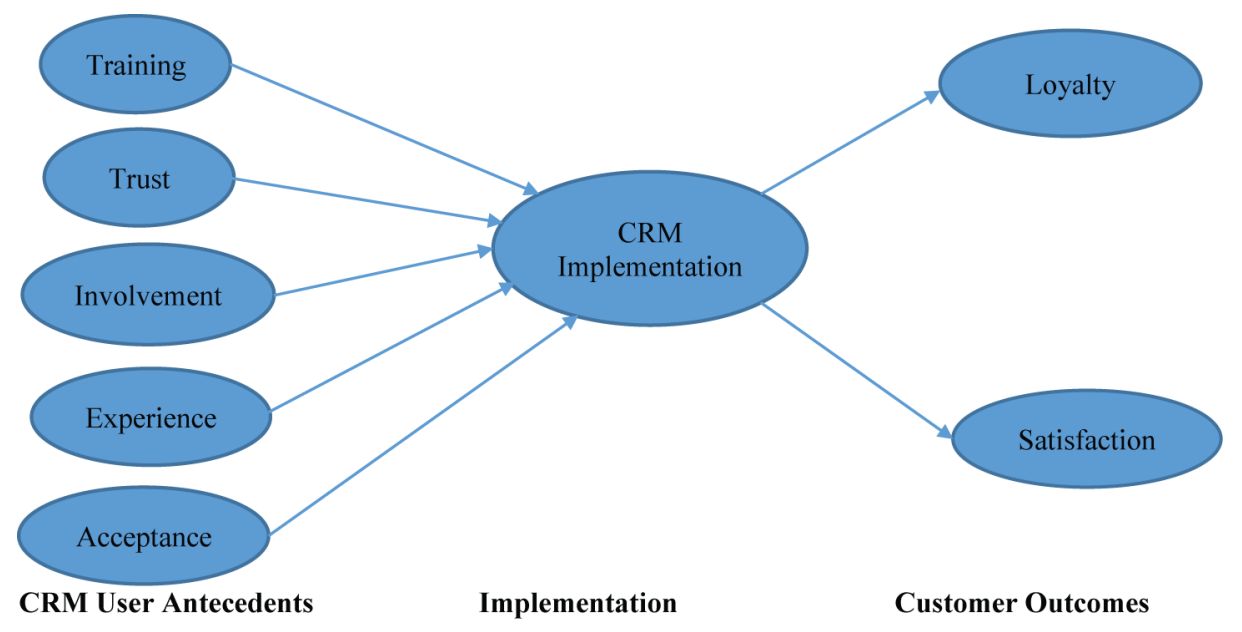

Moreover, as a result of the scarcity of studies in developing countries, user antecedents remain under-examined. However, these antecedents need to be investigated from the perspective of CRM users in the service industry with respect to customer outcomes in developing countries. To achieve this, the current study utilized a combined model that included the antecedents of CRM use, CRM implementation, and customer outcomes in a service industry context in Jordan.

\section{RESEARCH MODEL AND HYPOTHESES}

According to the current body of literature, the conceptual research model (see Figure 1) was built upon existing links between the acceptance of CRM technology (Davis, 1989; Chong et al., 2010), the antecedents of technology adoption, the customer loyalty level (Feliks \& Panjaitan, 2012; Khaligh et al., 2012), customer satisfaction level (Hanley \& Leahy, 2008), and retention level (Calik \& Balta, 2006).

\subsection{Training}

It is crucial for employees to receive training in the use of CRM. This will help users understand the operation of the CRM system and its perceived benefits for both organizations and customers (Avlonities et al., 2005; Davis et al., 1989; Dubey \& Sangle, 2019; Igbaria, 1990). Training should be supported by top management through adoption encouragement and budget allocation (Guenzi \& Nijssen, 2020; Padilla-Meléndez \& Garrido-Moreno, 2014; Padma \& Wagenseil, 2018; Papadopoulos et al., 2012). For instance, Dubey and Sangle (2019) and Chen et al. (2007) found that CRM training and CRM employee knowledge are factors that are clearly associated with successful CRM implementation. Consequently, the following hypothesis was proposed:

H1: There is a significant and positive relationship between training and CRM implementation.

\subsection{User Trust}

Trust is a significant factor affecting customer behavior that ensures the effectiveness of adopting certain technologies (Yang et al., 2013). Amin (2007) verified that integrity is central to the application of the system. Trust reflects customers' confidence in the integrity of the organization and could help sustain its relationship with its customers (Fernandes \& Pinto, 2019). However, an element that affects trust in the technology is whether or not the system is secure (Chong et al., 2010; Roberts-Lombard, 
2020). Bhat et al. (2018) found that a strong relationship between trust and loyalty increases CRM orientations. Therefore, the following hypothesis was proposed:

H2: There is a significant and positive relationship between trust and CRM implementation.

\subsection{User Involvement}

A large number of companies implementing new IT projects have encountered numerous problems in ensuring good usability of the final product (Redlarski, 2013). CRM initiatives can sometimes fail because the users who must work with the system do not accept it and therefore do not change the way in which they work (King \& Burgess, 2008; Foss et al., 2008). Avlonities et al. (2005) argued that user involvement and participation help them accept the CRM system and its applications. Therefore, the following hypothesis was proposed:

H3: There is a significant and positive relationship between user involvement and CRM implementation.

\subsection{User Experience}

A user's technical experience may have a critical impact on their understanding and attitudes toward intention to use or system usage. Several studies have examined the connection between attitudes and technical experience, most of which have identified a definitive relationship (Thompson et al., 1994). Moreover, the experience of CRM users plays an important role in CRM implementation because it influences their belief structure regarding an IS (Dubey \& Sangle, 2019; Cherapanukorn, 2019; Cruz-Jesus et al., 2019). Therefore, the following hypothesis was proposed:

H4: There is a significant and positive relationship between user experience and CRM implementation.

\subsection{User Acceptance}

A large number of studies have been conducted on IT acceptance over many decades (e.g. Davis, 1989). It is not possible for users to be involved in developing CRM software because CRM systems are normally purchased from external vendors; users generally only become involved subsequent to the installation of the system. However, it is only at this stage that minor adjustments can be made within the CRM systems and to applications (Gefen \& Ridings, 2003). Pai and Tu (2011) confirmed that the acceptance of technologies such as CRM could give organizations numerous advantages. Therefore, the following hypothesis was proposed:

H5: There is a significant and positive relationship between user acceptance and CRM implementation.

\subsection{Customer Outcomes}

\subsubsection{Customer Loyalty}

Scholars and practitioners assert that customer relationships are essential if companies are to succeed in reducing costs and increasing loyalty in the contemporary business setting (Kebede \& Tegegne, 2018; Suoniemi et al., 2021). Furthermore, maintaining enduring relationships with customers is crucial if companies are to survive in competitive service industries (Lindgreen et al., 2006). Sadia et al. (2011) found that customer loyalty is formed primarily by trust, staff loyalty, service quality, and switching costs. Additionally, extant studies (De Wulf et al., 2001; Kim et al., 2004; Szczepańska \& Gawron, 2011) have identified a decisive connection between CRM implementation and customer loyalty. Therefore, the following hypothesis was proposed: 
H6: There is a significant and positive relationship between CRM implementation and customer loyalty.

\subsubsection{Customer Retention}

Numerous studies have indicated that the cost of attracting new customers is greater than implementing a strategy to retain current customers (Gee et al., 2008; KHOA, 2020; Lee-Kelley et al., 2003). Calik and Balta (2006) and other researchers (e.g., Parida \& Baksi, 2011) argued that customer retention can yield a number of corporate advantages, including a reduction in operational expenses, and that new customers can be won through word-of-mouth referrals, thereby increasing revenue. The goal of customer retention is to reduce the number of customer defections and complaints, and to ensure customers return (Kebede \& Tegegne, 2018). Therefore, the following hypothesis was proposed:

H7: There is a significant and positive relationship between CRM implementation and customer retention.

\subsubsection{Customer Satisfaction}

Customer satisfaction is the best indicator for evaluating business and marketing performance (Wetsch, 2006; Tuli \& Bharadwaj, 2009) and is the key driver of profits (Roberts-Lombard, 2020). Additionally, Azzam (2014) and Rahimi and Kozak (2017) highlighted the importance of CRM implementation in improving customer satisfaction. Similarly, Feliks and Panjaitan (2012) postulated that organizations that implement CRM correctly increase customer satisfaction. For instance, a study by Hanley and Leahy (2008) concluded that CRM implementation has a significant and decisive impact on customer satisfaction. Therefore, the following hypothesis was proposed:

H8: There is a significant positive relationship between CRM implementation and customer satisfaction.

\section{EMPIRICAL STUDY}

\subsection{Research Instrument and Sample Size}

To test the proposed hypotheses and model, a survey of employees and managers in Jordan was conducted to gather the necessary data. The survey questionnaire was designed based on the literature. Once constructed, it was sent to two experts in CRM in two banks and one academic expert in CRM (a PhD holder with substantial experience in CRM research). The questionnaire was then modified according to their minor comments and suggestions.

The questionnaire comprised two sections. The first gathered demographic data about the participants and the companies. Respondents were asked about the following: 1) Industry type. 2) Size of the firm. 3) Firm's customers. 4) Age. 5) Position held. 6) Education level. The second part contained questions related to the variables included in the proposed model. A seven-point scale was employed to measure the variables. The items selected were chosen from previous studies measuring each variable.

The questionnaire was distributed to employees who occupied managerial positions involving CRM implementation and outcome assessments in the two largest cities in Jordan (Amman and Zarqa). These employees worked for companies in the following industrial fields: insurance, hotels, banking, and others. They were selected because a contact person was available to facilitate the process of collecting data and these companies had also implemented CRM.

The questionnaire was administered by the researchers. Table 1 presents the demographic data for the respondents. Overall, 500 questionnaires were distributed (face to face), of which 350 were 
Table 1. Demographic characteristics of the sample

\begin{tabular}{|l|l|l|}
\hline \multicolumn{1}{|c|}{ Characteristics } & No. of Respondents & \\
\hline 1. Firm & & \\
Industry & 88 & 30.3 \\
Insurance & 107 & 36.9 \\
Hotels & 80 & 27.6 \\
Banking & 15 & 5.2 \\
Others & & \\
\hline Size of the firm & 20 & 6.9 \\
< 50 & 155 & 53.5 \\
$50-100$ & 82 & 28.3 \\
$101-200$ & 33 & 11.3 \\
$>$ 200 & & \\
\hline Firm's Customers & 65 & 22.4 \\
Business (B2B) & 130 & 44.8 \\
Individual (B2C) & 95 & 32.8 \\
Both & & \\
\hline 2. Personal & & \\
Age (years) & 33 & 11.4 \\
<25 & 77 & 26.6 \\
26-35 & 81 & 27.9 \\
36-45 & 99 & 34.1 \\
\hline 45 & & \\
\hline Position held & 68 & 23.5 \\
Top level & 117 & 40.3 \\
Middle level & 79 & 27.2 \\
First-line & 26 & 9.0 \\
Others & & \\
\hline Education level & 55 & 73.1 \\
Secondary/high school & 212 & 7.9 \\
Undergraduate & 23 & \\
Post-graduate & & \\
\hline
\end{tabular}

returned and 290 were included in the analysis. In terms of the specific industries, the respondents were distributed as follows: 1) insurance sector: 88 completed questionnaires (30.3\%); 2) hotels: 107 (36.9\%); 3) banking: 80 (27.6\%); and 4) others: 15 (5.2\%).

Bartlett's Test of Sphericity is a statistical test employed to establish the suitability of factor analysis. It explores the entire correlation matrix, and a significance level of $\mathrm{P}<0.05$ is considered suitable. Table 2 indicates that the $\mathrm{P}$ value is below 0.001 with $\chi_{780}^{2}=9216.883$. It also illustrates that the value of the Kaiser-Meyer-Okliws (KMO) test exceeds the suggested minimum value of 0.6 (0.940), which indicates small correlations between variables.

\section{Table 2. KMO and Bartlett's Test}

\begin{tabular}{|l|l|l|}
\hline \multicolumn{2}{|l|}{ Kaiser-Meyer-Olkin Measure of Sampling Adequacy } & 0.940 \\
\hline \multirow{2}{*}{ Bartlett's Test of Sphericity } & Approx. Chi-Square & 9216.883 \\
\cline { 2 - 3 } & df & 780 \\
\cline { 2 - 3 } & Sig. & .000 \\
\hline
\end{tabular}




\subsection{Results and Discussion}

In this study, CRM implementation was hypothesized to be affected by five CRM user antecedents (training, trust, involvement, experience, and acceptance) (see The Proposed Model, Figure 1) which in turn will affect customer outcomes (loyalty, retention, and satisfaction).

Exploratory factor analysis (EFA) in the form of principal component analysis (PCA) was used to ensure that all the factors differed from each other. As shown in Table 3, the factor loading exceeded 0.4 (Nunnally, 1978) for all items after deleting the cross-loaded items on several factors that exceeded 0.5 . PCA revealed the presence of nine factors with an explained cumulative variance of $75 \%$. Consequently, all the factors in the proposed model differed from each other and were extracted.

Structural equation modelling (SEM) was then applied to analyze the structural model and its evaluation using AMOS 24. SEM was chosen due to its ability to assess causal connections between variables (constructs) with multiple evaluation items (Hair et al., 2006). Anderson and Gerbing (1988) proposed a two-step approach for SEM. The first step is to provide an approximate assessment of the measurement model, and the second is to estimate the structural model. Although SEM methodology was employed, the study must still be regarded as exploratory.

\subsubsection{The Measurement Model}

Within the measurement model, constructs (variables) are unobserved variables that cannot be measured directly but can be measured by variables known as indicators. Confirmatory factor analysis (CFA) was undertaken for the proposed measurement model, modified according to the values of the modification indices, and standardized residuals (Anderson \& Gerbing, 1988; Byrne, 1998; Segars, 1997). A measurement model with a satisfactory model fit was obtained after the required modifications were applied. The ratio CMIN/df (2.381) was below 3.0, RMSEA (0.069) was below 0.08 , and IFI (0.917) and CFI (0.916) were both above the acceptable level of 0.90 .

Discriminant validity, convergent validity, and reliability were assessed to evaluate the adequacy of the measurement model. Reliability indicates the degree to which the constructs are free of error and produce consistent results. Cronbach's Alpha was applied to assess the reliability, the value of which should be over 0.7 (Nunnally, 1978). Table 4 indicates that the reliability of all constructs ranged from 0.794 (training) to 0.906 (satisfaction), indicating good internal consistency and thus high reliability of the instrument. Additionally, composite reliability (CR) was applied to assess the internal consistency of the measurement model. Table 4 indicates that the CR values of all constructs ranged from 0.800 to 0.884 , which exceeded 0.7 and were thus regarded as satisfactory (Hair et al., 2006).

After obtaining the best-fitting measurement model, discriminant and convergent validities were evaluated. Convergent validity is the level to which multiple factors evaluating the same concept conform. Table 4 indicates that all item factor standardized loadings in the range of 0.735 to 0.900 were important and exceeded the suggested minimum factor loading of 0.707 (Gefen et al., 2000). Additionally, an average variance extracted (AVE) of 0.5 or higher is a good estimate that implies satisfactory convergence (Fornell \& Larcker, 1981). Table 4 shows that all AVEs were in the range between 0.526 and 0.717 .

Discriminant validity is the level to which the evaluations of various concepts are distinct and are present when the relationships between indicators that measure various factors are not too high; consequently, factor correlations are only of medium strength (e.g., < 0.85) (Kline, 2015). Table 5 shows that the factor correlation coefficients ranged from 0.353 to 0.804 , which indicated that the nine constructs were correlated but statistically separate and thus provided powerful evidence of discriminant validity.

In summary, the reliability as well as the discriminant and convergent validity of the measurement model were all confirmed. 
Table 3. Rotated component matrix

\begin{tabular}{|c|c|c|c|c|c|c|c|c|c|}
\hline & 1 & 2 & 3 & 4 & 5 & 6 & 7 & 8 & 9 \\
\hline SAT1 & .769 & & & & & & & & \\
\hline SAT2 & .774 & & & & & & & & \\
\hline SAT3 & .732 & & & & & & & & \\
\hline SAT4 & .709 & & & & & & & & \\
\hline SAT5 & .723 & & & & & & & & \\
\hline SAT6 & .669 & & & & & & & & \\
\hline LOY1 & & & & .616 & & & & & \\
\hline LOY3 & & & & .730 & & & & & \\
\hline LOY4 & & & & .544 & & & & & \\
\hline LOY5 & & & & .614 & & & & & \\
\hline LOY6 & & & & .529 & & & & & \\
\hline IMP1 & & & & & & & & .570 & \\
\hline IPM2 & & & & & & & & .611 & \\
\hline IPM3 & & & & & & & & .610 & \\
\hline IMP4 & & & & & & & & .563 & \\
\hline $\mathrm{ACC} 1$ & & & & & & & & & .562 \\
\hline $\mathrm{ACC} 3$ & & & & & & & & & .704 \\
\hline $\mathrm{ACC} 4$ & & & & & & & & & .625 \\
\hline TRA2 & & & & & & .773 & & & \\
\hline TRA3 & & & & & & .839 & & & \\
\hline TRA4 & & & & & & .733 & & & \\
\hline EXP1 & & & & & .707 & & & & \\
\hline EXP2 & & & & & .843 & & & & \\
\hline EXP3 & & & & & .851 & & & & \\
\hline TRU1 & & & .628 & & & & & & \\
\hline TRU2 & & & .791 & & & & & & \\
\hline TRU3 & & & .784 & & & & & & \\
\hline TRU4 & & & .723 & & & & & & \\
\hline INV1 & & & & & & & .791 & & \\
\hline INV2 & & & & & & & .841 & & \\
\hline INV3 & & & & & & & .544 & & \\
\hline RET1 & & .512 & & & & & & & \\
\hline RET2 & & .618 & & & & & & & \\
\hline RET3 & & .773 & & & & & & & \\
\hline RET4 & & .757 & & & & & & & \\
\hline RET5 & & .772 & & & & & & & \\
\hline
\end{tabular}


Table 4. Reliability and convergent validity

\begin{tabular}{|c|c|c|c|c|c|}
\hline Factor & Variables & $\begin{array}{c}\text { Standardized } \\
\text { Loadings } \\
(>\mathbf{0 . 7 0 7})^{\mathrm{a}}\end{array}$ & $\begin{array}{c}\text { AVE } \\
(>0.5)^{a}\end{array}$ & $\begin{array}{c}\text { Composite } \\
\text { Reliability } \alpha \\
(>0.7)^{\mathrm{a}}\end{array}$ & $\begin{array}{c}\text { Cronbach's } \\
\text { Alpha } \\
(>\mathbf{0 . 7})^{\mathrm{a}}\end{array}$ \\
\hline \multirow{2}{*}{ Training } & TRA2 & 0.815 & \multirow{2}{*}{0.661} & \multirow{2}{*}{0.800} & \multirow{2}{*}{0.794} \\
\hline & TRA3 & 0.811 & & & \\
\hline \multirow{4}{*}{ Trust } & TRU1 & 0.774 & \multirow{4}{*}{0.627} & \multirow{4}{*}{0.870} & \multirow{4}{*}{0.868} \\
\hline & TRU2 & 0.755 & & & \\
\hline & TRU3 & 0.852 & & & \\
\hline & TRU4 & 0.782 & & & \\
\hline \multirow{2}{*}{ Involvement } & INV1 & 0.900 & \multirow{2}{*}{0.717} & \multirow{2}{*}{0.835} & \multirow{2}{*}{0.831} \\
\hline & INV2 & 0.790 & & & \\
\hline \multirow{3}{*}{ Experience } & EXP1 & 0.768 & \multirow{3}{*}{0.706} & \multirow{3}{*}{0.878} & \multirow{3}{*}{0.874} \\
\hline & EXP2 & 0.863 & & & \\
\hline & EXP3 & 0.885 & & & \\
\hline \multirow{3}{*}{ Acceptance } & $\mathrm{ACC} 1$ & 0.862 & \multirow{3}{*}{0.693} & \multirow{3}{*}{0.871} & \multirow{3}{*}{0.871} \\
\hline & ACC3 & 0.803 & & & \\
\hline & $\mathrm{ACC} 4$ & 0.831 & & & \\
\hline \multirow{4}{*}{ Loyalty } & LOY1 & 0.735 & \multirow{4}{*}{0.646} & \multirow{4}{*}{0.879} & \multirow{4}{*}{0.878} \\
\hline & LOY3 & 0.817 & & & \\
\hline & LOY4 & 0.837 & & & \\
\hline & LOY6 & 0.823 & & & \\
\hline \multirow{3}{*}{ Retention } & RET2 & 0.810 & \multirow{3}{*}{0.647} & \multirow{3}{*}{0.845} & \multirow{3}{*}{0.838} \\
\hline & RET3 & 0.877 & & & \\
\hline & RET4 & 0.718 & & & \\
\hline \multirow{5}{*}{ Satisfaction } & SAT1 & 0.751 & \multirow{5}{*}{0.526} & \multirow{5}{*}{0.884} & \\
\hline & SAT2 & 0.816 & & & \\
\hline & SAT3 & 0.840 & & & 0.906 \\
\hline & SAT5 & 0.832 & & & \\
\hline & SAT6 & 0.818 & & & \\
\hline & IPM1 & 0.802 & & & \\
\hline CDM Imolomotion & IPM2 & 0.754 & 0640 & 0801 & 0870 \\
\hline CRM Implementation & IMP3 & 0.840 & 0.649 & 0.881 & 0.879 \\
\hline & IMP4 & 0.823 & & & \\
\hline
\end{tabular}

aRecommended value

\subsubsection{Structural Model Analysis and Hypotheses Testing}

In the second stage, structural equation modelling (SEM) was applied to evaluate the hypotheses (Figure 2). First, the overall model fit was examined. A model is considered to fit the observed data if the covariance matrix to which it implies is equal to the observed covariance matrix (Hoyle, 1995). Four common indices of fit were employed in this study (Hu et al., 1999; Ngai et al., 2007). A CMIN/ 
Table 5. Factor correlations

\begin{tabular}{|l|l|l|l|l|l|l|l|l|l|}
\hline & $\begin{array}{c}\text { CRM } \\
\text { Imp }\end{array}$ & \multicolumn{1}{|c|}{ SAT } & RET & LOY & ACC & EXP & INV & TRU & TRA \\
\hline CRM Imp & 1 & & & & & & & & \\
\hline SAT & 0.804 & 1 & & & & & & & \\
\hline RET & 0.625 & 0.557 & 1 & & & & & & \\
\hline LOY & 0.789 & 0.719 & 0.73 & 1 & & & & & \\
\hline ACC & 0.802 & 0.705 & 0.667 & 0.781 & 1 & & & & \\
\hline EXP & 0.516 & 0.449 & 0.614 & 0.568 & 0.48 & 1 & & & \\
\hline INV & 0.463 & 0.44 & 0.592 & 0.43 & 0.487 & 0.413 & 1 & & \\
\hline TRU & 0.576 & 0.598 & 0.618 & 0.594 & 0.587 & 0.452 & 0.565 & 1 & \\
\hline TRA & 0.454 & 0.476 & 0.353 & 0.393 & 0.403 & 0.378 & 0.487 & 0.4 & 1 \\
\hline
\end{tabular}

Figure 2. Measurement model

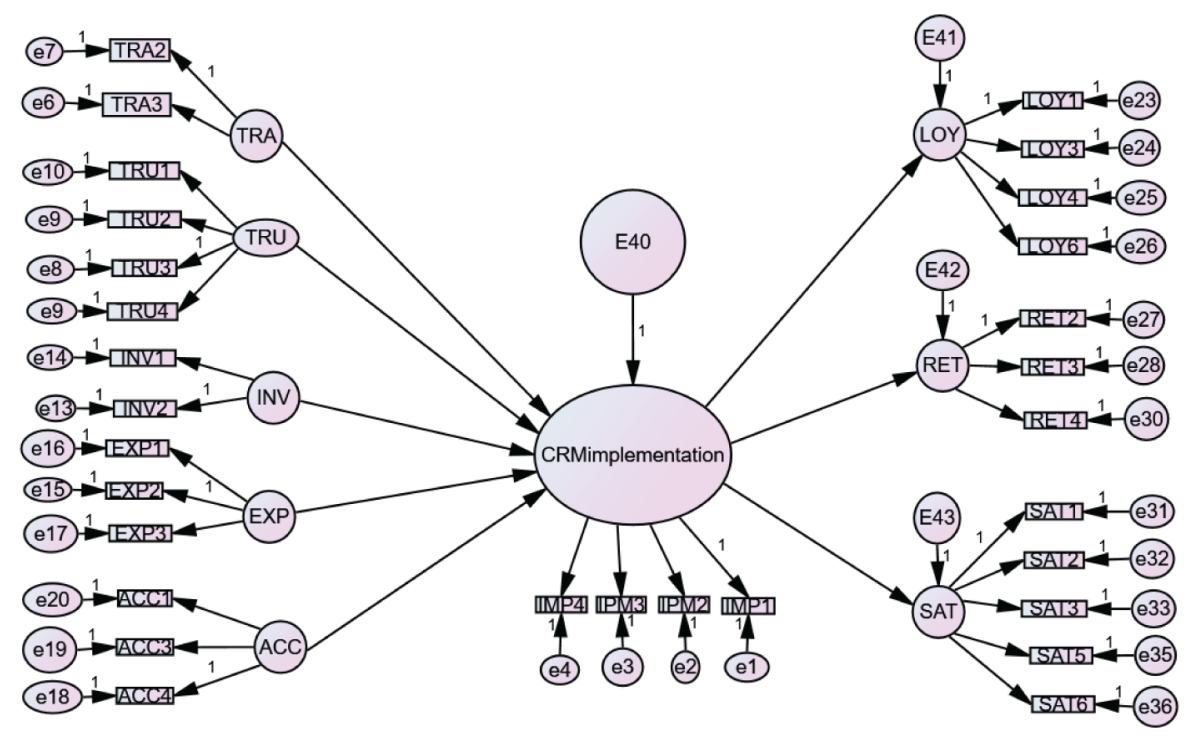

df of below 3, IFI and CFI above 0.9, and RMSEA below 0.08 are regarded as indicators of a good fit. All goodness-of-fit statistics $(\mathrm{CMIN} / \mathrm{df}=2.561, \mathrm{IFI}=0.902, \mathrm{CFI}=0.901$, and $\mathrm{RMSEA}=0.073$ ) therefore fit the data satisfactorily.

Table 6 depicts the outcome of the tests of relationships with path coefficients, P-values, and significance results. All relationships were statistically significant, except for the relationship between involvement and CRM implementation. This provides empirical support for most of the relationships in the proposed model. Experience and acceptance have a direct and significant effect on CRM implementation with $\mathrm{P}<0.001$. Training and trust have a direct and significant effect on 
Table 6. Results of path tests

\begin{tabular}{|l|l|l|l|l|l|l|l|}
\hline & & & \multicolumn{1}{|c|}{ Estimate } & \multicolumn{1}{|c|}{ S.E. } & \multicolumn{1}{|c|}{ C.R. } & \multicolumn{1}{|c|}{ P } & \multicolumn{1}{c|}{ Comment } \\
\hline CRMimplementation & $<---$ & TRA & 0.072 & 0.039 & 1.833 & 0.067 & Sig. * \\
\hline CRMimplementation & $<---$ & TRU & 0.153 & 0.058 & 2.654 & 0.008 & Sig. ** \\
\hline CRMimplementation & $<---$ & INV & -0.001 & 0.045 & -0.023 & 0.982 & Not Sig. \\
\hline CRMimplementation & $<---$ & EXP & 0.126 & 0.035 & 3.581 & $* * *$ & Sig. \\
\hline CRMimplementation & $<---$ & ACC & 0.593 & 0.059 & 9.96 & $* * *$ & Sig. \\
\hline LOY & $<---$ & CRMimplementation & 0.868 & 0.075 & 11.618 & $* * *$ & Sig. \\
\hline RET & $<---$ & CRMimplementation & 0.814 & 0.078 & 10.396 & $* * *$ & Sig. \\
\hline SAT & $<---$ & CRMimplementation & 0.864 & 0.072 & 11.927 & $* * *$ & Sig. \\
\hline
\end{tabular}

${ }^{*}$ Significant at $0.10,{ }^{* *}$ Significant at 0.05

CRM implementation with $\mathrm{P}<0.1$ and $\mathrm{P}<0.05$, respectively. Involvement has no impact on $\mathrm{CRM}$ implementation. However, CRM implementation has a direct and significant impact on all customer outcomes (loyalty, satisfaction, and retention) with $\mathrm{P}<0.001$.

As shown in Table 6, all the hypotheses were significant, except the one that relate user involvement with CRM implementation. The structural model analysis was conducted to test our hypotheses regarding user antecedents, CRM implementation, and customer outcomes. The results revealed that the antecedent variables of user training $(\mathrm{H} 1)(\beta=0.072, \mathrm{P}=0.067<0.10$, accept $)$, user trust $(\mathrm{H} 2)(\beta=0.153, \mathrm{P}=0.008<0.10$, accept $)$, user experience $(\mathrm{H} 4)(\beta=0.126, \mathrm{P}=0.000<$ 0.05 , accept $)$ and user acceptance $(\mathrm{H} 5)(\beta=0.593, \mathrm{P}=0.000<0.05)$ all have significant effects on CRM implementation. However, user involvement $(\mathrm{H} 3)(\beta=-0.001, \mathrm{P}=0.982<0.05$, reject $)$ was not significant. The results also indicated that the subsequent implementation of CRM has a significant effect on the customer outcomes of loyalty $(\mathrm{H} 6)(B=0.868, \mathrm{P}=0.000<0.05)$, retention $(\mathrm{H} 7)(B$ $=0.814, \mathrm{P}=0.000<0.05$, accept $)$, and satisfaction $(\mathrm{H} 8)(B=0.864, \mathrm{P}=0.000<0.05$, accept $)$.

\section{DISCUSSION}

The hypothesis stating that the level of training positively influences CRM implementation was supported $(\mathrm{B}=0.072, \mathrm{P}=0.067<0.1)$. In line with extant studies (e.g., Chen \& Popovich, 2003; Padilla-Meléndez \& Garrido-Moreno, 2014; Papadopoulos et al., 2012; Shum et al., 2008), this verifies that employees can share concepts and knowledge and form good relationships with customers as training in CRM packages was effective. Such training methods can allow organizations not only to develop a customer outcome strategy, but also to educate employees on how to effectively use CRM as a tool (Mendoza et al., 2007).

The hypothesis stating that the level of trust has a positive effect on CRM implementation was supported $(\mathrm{B}=0.153 ; \mathrm{P}=0.008<0.05)$. This is in line with the existing literature (Law et al., 2005; Yaghoubi et al., 2017). In fact, organizations often regard trust as an important ingredient in forging successful relationships between the end-user and CRM systems, and as being extremely crucial for user-friendly orientations. Therefore, if there is mistrust between the user and CRM systems, organizations will not be able to manage the uncertainties associated with CRM project implementation.

The hypothesis stating that the level of user involvement has a decisive effect on CRM implementation was not supported $(\mathrm{B}=-0.001 ; \mathrm{P}=0.982>0.05)$. Through participation of the end-user in system requirements, organizations are able to initiate, develop, and enhance connections with users' expectations and the CRM system itself; this is likely to lead to a commitment to usage 
and implementation (Shang \& Lin, 2010; Sindakis et al., 2015). It is therefore surprising that this hypothesis was not supported by the data from the Jordanian service industry respondents. A possible explanation is that top management may not support user involvement in the initial stages of CRM implementation.

The hypothesis stating that the level of user experience positively influences CRM implementation was supported $(\mathrm{B}=0.126, \mathrm{P}=0.000<0.05)$. Several extant studies confirm user experiences as one of the successful antecedents of CRM implementation (Dubey \& Sangle, 2019; Cherapanukorn, 2019; Malthouse et al., 2013; Thompson et al., 1994). To facilitate the interaction between CRM systems and end users, organizations support end-user employees by providing relevant software packages. They also train their employees to offer various IT solutions that will enable them to build successful connections with customers. In the same vein, with respect to user antecedents, the hypothesis stating that the level of user acceptance positively influences $C R M$ implementation was supported $(B=.593$, $\mathrm{P}=0.000<0.05)$. This is in line with existing studies that suggest that user acceptance plays a critical role in the CRM implementation process (George et al., 2005; Navimipour \& Soltani, 2016).

The hypothesis stating that the level of CRM implementation has a decisive impact on customer outcomes (customer loyalty, customer satisfaction, and customer retention) appears to be justified (Table 6). For instance, the hypothesis stating that the level of CRM implementation influences customer loyalty was significant $(\mathrm{B}=0.868, \mathrm{P}=0.000<0.05)$, which is in line with previous research (Lam et al., 2013; Lawson-Body \& Limayem, 2004; Szczepańska \& Gawron, 2011). This is perhaps because the implementation of CRM provides an opportunity for organizations in the service industry to build relations with customers, which simplifies the sales cycle, while the forging of one-to-one relationships possibly encourages customer loyalty. To increase customer loyalty, the Jordanian service industry should spend more time and resources developing effective CRM implementation projects (Al-Weshah et al., 2019).

The hypothesis stating that the level of CRM implementation influences customer retention was supported $(\mathrm{B}=0.814, \mathrm{P}=0.000<0.05)$. In line with previous studies (Parida \& Baksi, 2011; Verhoef, 2003), CRM implementation can help reduce operational and information sharing costs and attract new customers. Consequently, this will lead to a positive change in management strategies, which will result in increased profits for service organizations.

The hypothesis stating that the level of CRM implementation influences customer satisfaction was supported $(\mathrm{B}=0.864, \mathrm{P}=0.000<0.05)$. This is in line with existing literature (Hanley \& Leahy, 2008; Feliks \& Panjaitan, 2012; Rahimi \& Kozak, 2017) indicating that a wide array of options contained within applications are integrated by CRM implementation to offer better solutions and increase customer satisfaction. Thus, the use of these options could lead to the proper sharing of information and the engagement of customers in CRM activities, which ultimately lead to satisfaction.

The results thus demonstrate that CRM implementation has a decisive effect on customer outcomes (customer satisfaction, customer retention, and customer loyalty). This result verifies the findings of previous studies (Brown \& Gulycz, 2002; Coulter, 2002; Hanley, 2008). It implies that end user employees who construct a good relationship with the CRM implementation process based on trust, involvement, acceptance, and experience will enhance customer outcomes (Szczepańska \& Gawron, 2011).

\section{IMPLICATIONS}

The extant literature reveals that numerous user CRM antecedents are closely associated with customer outcomes (satisfaction, retention, and loyalty). The current study has also found that CRM has a direct and decisive association with customer satisfaction, customer loyalty, and customer retention. CRM user antecedents are intended to have an important influence on CRM implementation. This therefore illustrates the advantages that can be attained via efficient CRM implementation through an understanding of the user antecedents that drive the process. 
The study has several managerial implications. For instance, it has yielded practical results that can be deployed by managers and practitioners in the implementation of CRM, which are likely to result in positive customer outcomes with respect to satisfaction, loyalty, and retention. Such customer outcomes are helpful for the development of sustainable links with customers. This is vitally important for service industries, particularly in developing nations such as Jordan.

It is essential for companies assessing CRM applications to comprehend how their development has an impact in terms of enhancing customer satisfaction and loyalty. Experiencing the advantages of CRM applications will therefore be helpful to managers who are currently assessing or implementing CRM applications. Organizations with strong customer connections are more likely to gain advantages from CRM implementation regarding customer loyalty, satisfaction, and retention. The results also suggest that organizations need to be prepared to share their customer-related information with stakeholders to acquire an advantage from CRM implementation and its associated applications.

\section{LIMITATIONS AND FUTURE WORK}

Despite the valuable findings that have emerged, certain limitations in the research need to be mentioned. Firstly, CRM implementation is a lengthy endeavor that cannot be fully captured by a questionnaire, which presents a snapshot of a specific point in time. Longitudinal studies are needed to verify the efficiency of CRM implementation in a turbulent service industry. Second, the antecedents were selected from the CRM user's perspective. Future research should consider the inclusion of other perspectives such as strategic, management and technological perspectives to acquire more in-depth information regarding CRM implementation. Finally, this study only focused on the service industry. For an extensive overview of CRM implementation in the area of services, operational, knowledge and strategic levels need to be explored in depth in future work. To develop a comprehensive model, additional antecedents have to be identified and tested in an integrated model.

\section{CONCLUSION}

CRM is implemented by numerous businesses all over the world. However, previous research has mainly focused on CRM implementation in developed countries, with minimal emphasis on developing countries. This study contributes significantly to our understanding of CRM implementation in Jordan, which is considered a developing country.

The objective of this study was to examine the potential relationship between CRM user antecedents, CRM implementation, and customer outcomes in terms of customer satisfaction, loyalty, and retention in developing countries. This was achieved by obtaining experiential evidence from CRM users of the service industry in Jordan. User involvement as an antecedent of CRM implementation was not found to have a significant effect. However, CRM implementation was found to have an important and decisive impact on customer outcomes.

The linkages between these variables are not only important for the customer-centric management system, but also represent an important tool for managers in making decisions to support CRM implementation and to enhance CRM capabilities within the service industry in Jordan. Consequently, organizations as service providers must place greater emphasis on user involvement. Moreover, as end-users in CRM implementation, employees are not merely users of CRM systems; they are also expected to provided important inputs with regard to the requirements and development of these systems. It is therefore essential for employees to be well trained so that they can respond effectively to customers and enhance customer satisfaction, retention, and loyalty. 


\section{REFERENCES}

Ahmad, R., \& Buttle, F. (2001). Customer retention: A potentially potent marketing management strategy. Journal of Strategic Marketing, 9(1), 29-45. doi:10.1080/713775729

Ajzen, I., \& Fishbein, M. (1980). Understanding attitudes and predicting social behavior. Prentice Hall.

Akroush, M. N., Dahiyat, S. E., Gharaibeh, H. S., \& Abu-Lail, B. N. (2011). Customer relationship management implementation. International Journal of Commerce and Management, 21(2), 158-190. doi:10.1108/10569211111144355

Al-Weshah, G. A., Al-Manasrah, E., \& Al-Qatawneh, M. (2019). Customer relationship management systems and organizational performance: Quantitative evidence from the Jordanian telecommunication industry. Journal of Marketing Communications, 25(8), 799-819. doi:10.1080/13527266.2018.1449007

Almotairi, M. A. (2010). Evaluation of the Implementation of CRM in Developing Countries (Doctoral dissertation). Brunel University Brunel Business School.

Alrousan, M. K., Al-Adwan, A. S., Al-Madadha, A., \& Al Khasawneh, M. H. (2020). Factors Affecting the Adoption of E-Marketing by Decision Makers in SMEs: Evidence From Jordan. International Journal of E-Business Research, 16(1), 1-27. doi:10.4018/IJEBR.2020010101

Ambler, T., \& Kokkinaki, F. (1997). Measures of marketing success. Journal of Marketing Management, 13(7), 665-678. doi:10.1080/0267257X.1997.9964503

Amin, H. (2007). Internet banking adoption among young intellectuals. Journal of Internet Banking and Commerce, 12(3).

Anderson, J. C., \& Gerbing, D. W. (1988). Structural equation modeling in practice: A review and recommended two-step approach. Psychological Bulletin, 103(3), 411-423. doi:10.1037/0033-2909.103.3.411

Anshari, M., Almunawar, M. N., Lim, S. A., \& Al-Mudimigh, A. (2019). Customer relationship management and big data enabled: Personalization \& customization of services. Applied Computing and Informatics, 15(2), 94-101. doi:10.1016/j.aci.2018.05.004

Appiah-Kubi, B. (2010). Towards a successful customer relationship management: A conceptual framework. African Journal of Marketing Management, 1(3), 37-43.

Arcand, M., PromTep, S., Brun, I., \& Rajaobelina, L. (2017). Mobile banking service quality and customer relationships. International Journal of Bank Marketing, 35(7), 1066-1087. doi:10.1108/IJBM-10-2015-0150

Avlonitis, G. J., \& Panagopoulo, N. G. (2005, May). Antecedents and consequences of CRM technology acceptance in the sales force. Industrial Marketing Management, 34(4), 355-368. doi:10.1016/j.indmarman.2004.09.021

Avlonitis, G. J., \& Panagopoulos, N. G. (2005). Antecedents and consequences of CRM technology acceptance in the sales force. Industrial Marketing Management, 34(4), 355-368. doi:10.1016/j.indmarman.2004.09.021

Azzam, K. (2014). The Impact of Customer Relationship Management on Customer Satisfaction in the Banking Industry-A Case of Jordan. European Journal of Business and Management, 6(32), 99-112.

Bahri-Ammari, N., \& Soliman, K. S. (2016). The effect of CRM implementation on pharmaceutical industry's profitability: The case of Tunisia. Management Research Review, 39(8), 854-878. doi:10.1108/MRR-11-2014-0258

Barsy, M. H. A. E. (2017). The Impact of Using Customer Relationship Management to Achieve Competitive Advantage for Egypt Air. Journal of Advanced Management Science, 5(3).

Bhat, S. A., Darzi, M. A., \& Parrey, S. H. (2018). Antecedents of customer loyalty in banking sector: A mediational study. Vikalpa, 43(2), 92-105. doi:10.1177/0256090918774697

Byrne, B. M. (1998). Multivariate applications book series. Structural equation modeling with LISREL, PRELIS, and SIMPLIS: Basic concepts, applications, and programming. Lawrence Erlbaum Associates Publishers.

Calik, N., \& Balta, N. F. (2006). Consumer satisfaction and loyalty derived from the perceived quality of individual banking services: A field study in Eskisehir from Turkey. Journal of Financial Services Marketing, 10(4), 135-149. doi:10.1057/palgrave.fsm.4760020 
Chen, H. M., Chen, Q., \& Kazman, R. (2007). The affective and cognitive impacts of perceived touch on online customers' intention to return in the Web-based e-CRM environment. Journal of Electronic Commerce in Organizations, 5(1), 69-91. doi:10.4018/jeco.2007010104

Chen, I. J., \& Popovich, K. (2003). Understanding customer relationship management (CRM) People, process and technology. Business Process Management Journal, 9(5), 672-688. doi:10.1108/14637150310496758

Chen, R. R., Ou, C. X., Wang, W., Peng, Z., \& Davison, R. M. (2020). Moving beyond the direct impact of using CRM systems on frontline employees' service performance: The mediating role of adaptive behaviour. Information Systems Journal, 30(3), 458-491. doi:10.1111/isj.12265

Cherapanukorn, V. (2019, November). Antecedents of eCRM success in the hospitality industry. In 2019 22nd International Symposium on Wireless Personal Multimedia Communications (WPMC) (pp. 1-6). IEEE.

Chiguvi, D., \& Mahambo, C. (2020). The Psychometric Properties of Customer Relationship Management Framework in the Local Government Authorities in Zimbabwe. Dutch Journal of Finance and Management, 4(2), em0069. doi:10.21601/djfm/9354

Chong, A. Y. L., Ooi, K. B., Lin, B., \& Tan, B. I. (2010). „Online banking adoption: An empirical analysis“. International Journal of Bank Marketing, 28(4), 267-287. doi:10.1108/02652321011054963

Christy, R., Oliver, G., \& Penn, J. (1996). Relationship marketing in consumer markets. Journal of Marketing Management, 12(1-3), 175-187. doi:10.1080/0267257X.1996.9964407

Cruz-Jesus, F., Pinheiro, A., \& Oliveira, T. (2019). Understanding CRM adoption stages: Empirical analysis building on the TOE framework. Computers in Industry, 109, 1-13. doi:10.1016/j.compind.2019.03.007

Das, S., Mishra, M., \& Mohanty, P. K. (2018). The impact of customer relationship management (CRM) practices on customer retention and the mediating effect of customer satisfaction. International Journal of Management Studies, 5(1 (4)), 95. doi:10.18843/ijms/v5i1(4)/15

Davis, F. D. (1989). Perceived usefulness, perceived ease of use, and user acceptance of information technology. Management Information Systems Quarterly, 13(3), 319-340. doi:10.2307/249008

Davis, F. D., Bagozzi, R. P., \& Warshaw, P. R. (1989). User acceptance of computer technology: A comparison of two theoretical models. Management Science, 35(8), 982-1003. doi:10.1287/mnsc.35.8.982

Day, G. S. (2002). Winning the competition for customer relationships management: Consequences for competitive advantage and performance. Marketing Science Institute, 2-123.

De Wulf, K., Odekerken-Schröder, G., \& Iacobucci, D. (2001). Investments in consumer relationships: A crosscountry and cross-industry exploration. Journal of Marketing, 65(4), 33-50. doi:10.1509/jmkg.65.4.33.18386

Diffley, S., McCole, P., \& Carvajal-Trujillo, E. (2018). Examining social customer relationship management among Irish hotels. International Journal of Contemporary Hospitality Management, 30(2), 1072-1091. doi:10.1108/IJCHM-08-2016-0415

Doyle, P. (1995). Marketing in the new millennium. European Journal of Marketing, 29(13), $23-41$. doi:10.1108/03090569510147712

Dubey, N. K., \& Sangle, P. (2019). Customer perception of CRM implementation in banking context. Journal of Advances in Management Research.

Dyché, J. (2002). The CRM handbook: A business guide to customer relationship management. Addison-Wesley Pearson Education.

El-Gohary, H., Edwards, D. J., \& Huang, J. (2013). Customer relationship management (CRM) practices by small businesses in developing economies: A case study of Egypt. International Journal of Customer Relationship Marketing and Management, 4(2), 1-20. doi:10.4018/jcrmm.2013040101

Eriksson, K., \& Vaghult, A. L. (2000). Customer retention, purchasing behavior and relationship substance in professional services. Industrial Marketing Management, 29(4), 363-372. doi:10.1016/S0019-8501(00)00113-9 
Farhan, M. S., Abed, A. H., \& Abd Ellatif, M. (2018). A systematic review for the determination and classification of the CRM critical success factors supporting with their metrics. Future Computing and Informatics Journal, 3(2), 398-416. doi:10.1016/j.fcij.2018.11.003

Feliks, \& Panjaitan. (2012).The Effects of Customer Relationship Management and Service Quality towards Customer Loyalty through Customer Satisfaction. The International Conference on Sustainable Development, 159-175.

Fernandes, T., \& Pinto, T. (2019). Relationship quality determinants and outcomes in retail banking services: The role of customer experience. Journal of Retailing and Consumer Services, 50, 30-41. doi:10.1016/j. jretconser.2019.01.018

Fornell, C., \& Larcker, D. F. (1981). Evaluating structural equation models with unobservable variables and measurement error. JMR, Journal of Marketing Research, 18(1), 39-50. doi:10.1177/002224378101800104

Foss, B., Stone, M., \& Ekinci, Y. (2008). What makes for CRM system success-Or failure? Journal of Database Marketing \& Customer Strategy Management, 15(2), 68-78. doi:10.1057/dbm.2008.5

Gee, R., Coates, G., \& Nicholson, M. (2008). Understanding and profitably managing customer loyalty. Marketing Intelligence \& Planning, 26(4), 359-374. doi:10.1108/02634500810879278

Gefen, D., \& Ridings, C. M. (2003). IT acceptance: Managing user-IT group boundaries. SIGMIS Database, 34(3), 25-40. doi:10.1145/937742.937746

Gefen, D., Straub, D., \& Boudreau, M. C. (2000). Structural equation modeling and regression: Guidelines for research practice. Communications of the Association for Information Systems, 4(1), 7. doi:10.17705/1CAIS.00407

Gil-Gomez, H., Guerola-Navarro, V., Oltra-Badenes, R., \& Lozano-Quilis, J. A. (2020). Customer relationship management: Digital transformation and sustainable business model innovation. Economic Research-Ekonomska Istraživanja, 33(1), 2733-2750. doi:10.1080/1331677X.2019.1676283

Guenzi, P., \& Nijssen, E. J. (2020). Studying the antecedents and outcome of social media use by salespeople using a MOA framework. Industrial Marketing Management, 90, 346-359. doi:10.1016/j.indmarman.2020.08.005

Hair, J., Black, B., Babin, B., Anderson, R. E., \& Tatham, R. L. (2006). Multivariate data analysis (6th ed.). Prentice Hall.

Hanley, S., \& Leahy, R. (2008). The effectiveness of relationship marketing strategies in department stores. International Journal of Business and Management, 3(10), 133-140.

Hoyle, R. H. (1995). The structural equation modeling approach basic concepts and fundamental issues. Sage publications.

Hu, P. J., Chau, P. Y., Sheng, O. R. L., \& Tam, K. Y. (1999). Examining the technology acceptance model using physician acceptance of telemedicine technology. Journal of Management Information Systems, 16(2), 91-112. doi:10.1080/07421222.1999.11518247

Igbaria, M. (1990). End-user computing effectiveness: A structural equation model. Omega, 18(6), 637-652. doi:10.1016/0305-0483(90)90055-E

Jaber, F., \& Simkin, L. (2017). Unpicking antecedents of CRM adoption: A two-stage model. Journal of Strategic Marketing, 25(5-6), 475-494. doi:10.1080/0965254X.2016.1149212

Jayachandran, S., Sharma, S., Kaufman, P., \& Raman, P. (2005). The role of relational information processes and technology use in customer relationship management. Journal of Marketing, 69(4), 177-192. doi:10.1509/ jmkg.2005.69.4.177

Karakostas, B., Kardaras, D., \& Papathanassiou, E. (2005). The state of CRM adoption by the financial services in the UK: An empirical investigation. Information \& Management, 42(6), 853-863. doi:10.1016/j.im.2004.08.006

Kebede, A. M., \& Tegegne, Z. L. (2018). The effect of customer relationship management on bank performance: In context of commercial banks in Amhara Region, Ethiopia. Cogent Business \& Management, $5(1), 1499183$. doi:10.1080/23311975.2018.1499183 
Khaligh, A., Miremadi, A., \& Aminilari, M. (2012). The Impact of eCRM on Loyalty and Retention of Customers in Iranian Telecommunication Sector. International Journal of Business and Management, 7(2), 150-162.

Khashab, B., Gulliver, S. R., \& Ayoubi, R. M. (2020). A framework for customer relationship management strategy orientation support in higher education institutions. Journal of Strategic Marketing, 28(3), $246-265$. doi:10.1080/0965254X.2018.1522363

Khoa, B. T. (2020). The antecedents of relationship marketing and customer loyalty: A case of the designed fashion product. The Journal of Asian Finance, Economics, and Business, 7(2), 195-204. doi:10.13106/ jafeb.2020.vol7.no2.195

Kim, J. W., Choi, J., Qualls, W., \& Park, J. (2004). The impact of CRM on firm-andrelationship-level performance in distributed networks. Communications of the Association for Information Systems, 14(1), 30.

King, S. F., \& Burgess, T. F. (2008). Understanding success and failure in customer relationship management. Industrial Marketing Management, 37(4), 421-431. doi:10.1016/j.indmarman.2007.02.005

Kline, R. B. (2015). Principles and practice of structural equation modeling. Guilford publications.

Kotler, P. (2003). Marketing Insights from A to Z. John Wiley and Sons.

Kotler, P., \& Armstrong, G. (2008). Principles of marketing (12th ed.). Pearson Prentice Hall.

Kotler, P., Armstrong, G., Sanders, J., \& Wong, V. (1999). Principles of Marketing, 2. Prentice-Hall.

Kotler, P., \& Keller, K. L. (2016). Marketing Management (15th Global Edition). Pearson Educationn Limited.

Lam, A. Y., Cheung, R., \& Lau, M. M. (2013). The influence of internet-based customer relationship management on customer loyalty. Contemporary Management Research, 9(4), 419-440. doi:10.7903/cmr.11095

Lambert, D. M. (2009). Customer relationship management as a business process. Journal of Business and Industrial Marketing, 25(1), 4-17. doi:10.1108/08858621011009119

Law, M., Wong, Y. H., \& Lau, T. (2005). The role of trust in customer relationship management: An example to financial services industry. Asia Pacific Management Review, 10(4), 267-274.

Lawson-Body, A., \& Limayem, M. (2004). The impact of customer relationship management on customer loyalty: The moderating role of web site characteristics. Journal of Computer-Mediated Communication, 9(4).

Lee-Kelley, L., Gilbert, D., \& Mannicom, R. (2003). How e-CRM can enhance customer loyalty. Marketing Intelligence \& Planning, 21(4), 239-248.

Lemon, K. N., \& Verhoef, P. C. (2016). Understanding customer experience throughout the customer journey. Journal of Marketing, 80(6), 69-96.

Lindgreen, A., Palmer, R., Vanhame, J., \& Wouters, J. (2006). A relationship-management assessment tool: Questioning, identifying, and prioritizing critical aspects of customer relationships. Industrial Marketing Management, 35(1), 57-71.

Maklan, S., \& Knox, S. (2009). Dynamic Capabilities: The missing link in CRM investments. European Journal of Marketing, 43(12), 1392-1410.

Malthouse, E. C., Haenlein, M., Skiera, B., Wege, E., \& Zhang, M. (2013). Managing customer relationships in the social media era: Introducing the social CRM house. Journal of Interactive Marketing, 27(4), 270-280.

Mandina, S. P. (2014). Contribution of CRM strategies in enhancing customer loyalty. Journal of Marketing Development and Competitiveness, 8(2), 69.

Mendoza, L. E., Marius, A., Pérez, M., \& Grimán, A. C. (2007). Critical success factors for a customer relationship management strategy. Information and Software Technology, 49(8), 913-945.

Mohammed, A., Rahid, B., \& Tahir. (2014). Customer relationship management (CRM) technology and organisation performance: Is marketing capability a missing link? An empirical study in the Malaysian hotel industry. Asian Social Science, (10), 197. 
Momanyi, L. M. (2010). Customer retention strategies adopted by mobile telecommunications companies in Kenya (Doctoral dissertation). University of Nairobi, Kenya.

Muketha, J. K., Thiane, K., \& Thuranira, L. (2016). Influence of relationship marketing on customer retention in the branches of commercial banks in Meru town, Kenya. Int. J. Adv. Multidiscip. Res, 3(11), 20-61.

Navimipour, N. J., \& Soltani, Z. (2016). The impact of cost, technology acceptance and employees' satisfaction on the effectiveness of the electronic customer relationship management systems. Computers in Human Behavior, $55,1052-1066$.

Ngai, E. W., Poon, J. K. L., \& Chan, Y. H. (2007). Empirical examination of the adoption of WebCT using TAM. Computers \& Education, 48(2), 250-267.

Ngai, E. W. T. (2005). Customer relationship management research (1992-2002): An academic literature review and classification. Marketing Intelligence \& Planning, 23(6), 582-605.

Nguyen, B. (2012). The dark side of customer relationship management: Exploring the underlying reasons for pitfalls, exploitation and unfairness. Journal of Database Marketing \& Customer Strategy Management, 19(1), 56-70.

Nguyen, T. H., Sherif, J. S., \& Newby, M. (2007). Strategies for successful CRM implementation. Information Management \& Computer Security, 15(2), 102-115.

Noor, N. A. M. (2013). Trust and commitment: Do they influence e-customer relationship performance? International Journal of Electronic Commerce Studies, 3(2), 281-296.

Nunnally, J. C. (1978). Psychometric theory (2nd ed.) McGraw-Hill.

Olavarría-Jaraba, A., Cambra-Fierro, J. J., Centeno, E., \& Vázquez-Carrasco, R. (2018). Relationship quality as an antecedent of customer relationship proneness: A cross-cultural study between Spain and Mexico. Journal of Retailing and Consumer Services, 42, 78-87.

Padilla-Meléndez, A., \& Garrido-Moreno, A. (2014). Customer relationship management in hotels: Examining critical success factors. Current Issues in Tourism, 17(5), 387-396.

Padma, P., \& Wagenseil, U. (2018). Retail service excellence: Antecedents and consequences. International Journal of Retail \& Distribution Management.

Padmavathy, C., Balaji, M. S., \& Sivakumar, V. J. (2012). Measuring effectiveness of customer relationship management in Indian retail banks. International Journal of Bank Marketing, 30(4), 246-266.

Pai, J. C., \& Tu, F. M. (2011). The acceptance and use of customer relationship management (CRM) systems: An empirical study of distribution service industry in Taiwan. Expert Systems with Applications, 38(1), 579-584.

Papadopoulos, T., Ojiako, U., Chipulu, M., \& Lee, K. (2012). The criticality of risk factors in customer relationship management projects. Project Management Journal, 43(1), 65-76.

Parawansa, D. A. S. (2018). Effect of commitment and customers' satisfaction on the relationship between service quality and customer retention in rural banks in Makassar, Indonesia. Journal of Management Development, $37(1), 53-64$.

Parida, B. B., \& Baksi, A. K. (2011). Customer retention and profitability: CRM environment. SCMS. Journal of Indian Management, 8(2), 66.

Parvatiyar, A., \& Sheth, J. (2001). Customer Relationship Management: Emerging Practice, Process and Discipline. Journal of Economic and Social Research, 3(2), 1-34.

Payne, A., \& Frow, P. (2006). Customer relationship management: From strategy to implementation. Journal of Marketing Management, 22(1-2), 135-168.

Plakoyiannaki, E. (2005). How do organizational members perceive CRM? Evidence form a U.K. service firm. Journal of Marketing Management, 21, 363-392.

Pozza, Goetz, \& Sahut. (2018). Implementation effects in the relationship between CRM and its performance. Journal of Business Research, 89, 391-403. 
Pullig, C., Maxham, J. G. III, \& Hair, J. F. Jr. (2002). Salesforce automation systems: An exploratory examination of organisational factors associated with effective implementation and salesforce productivity. Journal of Business Research, 55(5), 401-415.

Qtaish, O., Fazea, Y., \& Abuhamdeh, M. (2018). Factors that affecting the Implementation of CRM in Commercial Banks. Quality - Access to Success, 19(167).

Rababah, K. (2013). Implementation methodology of customer relationship management (CRM) systems: Towards developing successful principles and guidelines. Academic Research International, 4(6), 551.

Rahimi, R. (2017). Customer relationship management (people, process and technology) and organisational culture in hotels. International Journal of Contemporary Hospitality Management.

Rahimi, R., \& Kozak, M. (2017). Impact of customer relationship management on customer satisfaction: The case of a budget hotel chain. Journal of Travel \& Tourism Marketing, 34(1), 40-51.

Redlarski, K. (2013, June). The impact of end-user participation in IT projects on product usability. In Proceedings of the International Conference on Multimedia, Interaction, Design and Innovation (p. 21). ACM.

Reichheld, F. F. (1996). The loyalty effect. Harvard Business School Press.

Roberts-Lombard, M. (2020). Antecedents and outcome of commitment in Islamic banking relationships-an emerging African market perspective. Journal of Islamic Marketing.

Rogers, E. M. (1983). Diffusion of innovations (3rd ed.). Free Press.

Sadia, J., Tasneem, F., \& Khan, M. (2011). An empirical analysis of customer loyalty in Pakistan's telecommunication industry. Journal of Database Marketing \& Customer Strategy Management, 18(1), 5-15.

Salloum, C., \& Ajaka, J. (2013). CRM Failure to apply optimal management information systems: Case of Lebanese financial sector. The Arab Economics and Business Journal, 8(1-2), 16-20.

Santouridis, I., \& Veraki, A. (2017). Customer relationship management and customer satisfaction: The mediating role of relationship quality. Total Quality Management \& Business Excellence, 28(9-10), 1122-1133.

Saxena, N., \& Taneja, M. (2018). A study on CRM effectiveness in public and private sector banks. International Journal of Public Sector Performance Management, 4(1), 45-56.

Šebjan, U., Bobek, S., \& Tominc, P. (2014). Organizational factors influencing effective use of CRM solutions. Procedia Technology, 16, 459-470.

Segars, A. H. (1997). Assessing the unidimensionality of measurement: A paradigm and illustration within the context of information systems research. Omega, 25(1), 107-121.

Shang, S. S. C., \& Lin, S. F. (2010). People-driven processes in customer relationship management. Service Industries Journal, 30(14), 2441-2456.

Shaon, S. K. I., \& Rahman, H. (2015). A theoretical review of CRM effects on customer satisfaction and loyalty. Central European Business Review, 4(1), 23.

Sheth, J. N., \& Sharma, A. (2008). The Impact of the Product to Service Shift in Industrial Markets and the Evolution of the Sales Organization. Industrial Marketing Management, 37(3), 260-269.

Shum, P., Bove, L., \& Auh, S. (2008). Employees' affective commitment to change: The key to successful CRM implementation. European Journal of Marketing, 42(11/12), 1346-1371.

Sibanda, V., \& Ndhlela, M. (2018). Customer Relationship Management as a Customer Retention Tool: A Case Study of OK Zimbabwe Limited. EPH-International Journal of Business \& Management Science, 4(2), $27-41$.

Sin, L. Y., Alan, C. B., \& Yim, F. H. (2005). CRM: Conceptualization and scale development. European Journal of Marketing.

Sindakis, S., Depeige, A., \& Anoyrkati, E. (2015). Customer-centered knowledge management: Challenges and implications for knowledge-based innovation in the public transport sector. Journal of Knowledge Management, 19(3), 559-578. 
Sota, S., Chaudhry, H., \& Srivastava, M. K. (2020). Customer relationship management research in hospitality industry: A review and classification. Journal of Hospitality Marketing \& Management, 29(1), 39-64.

Suoniemi, S., Terho, H., Zablah, A., Olkkonen, R., \& Straub, D. W. (2021). The impact of firm-level and projectlevel it capabilities on CRM system quality and organizational productivity. Journal of Business Research, 127, $108-122$.

Swift, R. S. (2001). Accelerating Customer Relationships: Using CRM and Relationship Technologies. PrenticeHall.

Szczepańska, K., \& Gawron, P. P. (2011). Changes in Approach to Customer Loyalty. Contemporary Economics, $5(1)$.

Tan, X., Yen, D. C., \& Fang, X. (2002). Internet integrated customer relationship management. Journal of Computer Information Systems, 77-86.

Tawinunt, K., Phimonsathienand, T., \& Fongsuwan, W. (2015). A structural equation model of customer relationship management factors affecting customer retention of long-stay travelers in the Thai tourism industry. Research Journal of Business Management, 9(1), 1-24.

Taylor, S., \& Todd, P. (1995). Decomposition and crossover effects in the theory of planned behavior: A study of consumer adoption intentions. International Journal of Research in Marketing, 12, 137-155.

Thompson, R. L., Higgins, C. A., \& Howell, J. M. (1994). Influence of experience on personal computer utilization: Testing a conceptual model. Journal of Management Information Systems, 11(1), 167-187.

Tuli, K. R., \& Bharadwaj, S. G. (2009). Customer satisfaction and stock returns risk. Journal of Marketing, 73, 184-197.

Tussyadiah, I. P. (2016). Factors of satisfaction and intention to use peer-to-peer accommodation. International Journal of Hospitality Management, 55, 70-80.

Vella, J., \& Caruana, A. (2012). Encouraging CRM systems usage: A study among bank managers. Management Research Review, 35(2), 121-133.

Venkatesh, V., Morris, M. G., Davis, G. B., \& Davis, F. D. (2003). User Acceptance of Information Technology: Toward a Unified View. Management Information Systems Quarterly, 27(3), 426-478.

Verhoef, P. C. (2003). Understanding the effect of customer relationship management efforts on customer retention and customer share development. Journal of Marketing, 67(4), 30-45.

Wetsch, L. R. (2006). Trust, satisfaction and loyalty in customer relationship management: An application of justice theory. Journal of Relationship Marketing, 4(3-4), 29-42.

Wu, I. L., \& Wu, K. W. (2005). A hybrid technology acceptance approach for exploring e-CRM adoption in organizations. Behaviour \& Information Technology, 24(4), 303-316.

Yaghoubi, M., Asgari, H., \& Javadi, M. (2017). The impact of the customer relationship management on organisational productivity, customer trust and satisfaction by using the structural equation model: A study in the Iranian hospitals. Journal of Education and Health Promotion, 6.

Yang, H., Wu, C., \& Wang, K. (2009). An empirical analysis of online game service satisfaction and loyalty. Expert Systems with Applications, 36(2), 1816-1825.

Yim, F., Anderson, R. E., \& Swaminathan, S. (2004). Customer relationship management: Its dimensions and effect on customer outcomes. Journal of Personal Selling \& Sales Management, 24(4), 263-278. 
Muneer Abbad is an associate professor in business administration with an emphasis on strategic management, leadership styles, and management information systems. Muneer Abbad received his PhD in business administration from Coventry University UK in 2009. Alongside his PhD, Muneer has an MBA from Jordan University, MSc in Finance and Banking from Yarmouk University, a BSc in Computer Engineering, BA in Business Administration, and a PGCTHE (Postgraduate Certificate of Teaching in Higher Education). His research interest includes organizational behavior and HRM.

Ibrahim Hussien Musa Magboul graduated from University of Khartoum (B.Sc, 1994; M.Sc Management, 2002) and PhD (Management) from Multimedia University, Malaysia (2013). He is an Assistant Professor in the department of Management Information System, Ahfad University for Women (AUW), Omdurman, Sudan. Dr. Magboul worked as a Dean of School of Management at AUW (2014-2016). Currently, he is an assistant Professor at Business department and Computer Science Community College of Qatar (CCQ). His research areas of interest are: technology adoption, information systems usage \& business functions, E-business, predictive analytics, Green IT, Instructional Technology in Education \& Quality Assurance Systems and technologies.

Wasfi Alrawabdeh is the present dean of the faculty of business and administration science at the Hashemite University in Jordan. Alrawabdeh holds a PhD in Marketing, post-graduate certificate in Social Science Research from the University of Kent, Kent, UK. He holds an MBA from Connecticut, USA. His current research interests include global e-commerce, commerce technology, e-business and adoption and use of IT. His academic recognition includes the Best PhD Poster Award from the University of Kent, Kent, UK. He has ten years of experience managing different department stores in the State of Connecticut, USA. 